\title{
Learning Local History in Pekalongan to Increase Solidarity of Vocational High School Students
}

\author{
Lidya D. Jayanti ${ }^{1}$, Sunardi ${ }^{1}$, Nunuk Suryani ${ }^{1}$ \\ ${ }^{1}$ Universitas Sebelas Maret \\ Email: lidyadwi.dwijayanti2@gmail.com
}

\begin{abstract}
Local history has role in building of student's solidarity. The solidarity focuses on the relationship among people in group and becomes the basic of life bounding with moral values and belief. Patriotic values in local history will be eternal if are applied in daily life so that can give the respond and answer the changing life. In this case the learning of local history has a strategic role to increase the social solidarity of vocational students. The method used in this research is qualitative descriptive. Based on the result of the research, student solidarity can be improved through the inculcation of local history learning values that is the Kebon Rojo incident on 3 October 1945 in Pekalongan. It can describe about the struggle of Pekalongan people in defending the independency of Indonesia by taking over the power and weapon from Japan. The patriotic values can be applied in daily life through education so that education can be seen as the effort to strengthen the nationality, religiousness, and solidarity.
\end{abstract}

\section{Keywords: Local History Learning; Student's Solidarity.}

\section{Introduction}

Every area in Indonesia has much diversity in many things, not only in history incident but also culture values that develops in our society as the national heritage. The history values become life guidance for generations [1]. The values are related to each other as a system and become one of local history.

Every area in Indonesia has a local history that can be studied for being developed in history learning. Local culture values or local culture incident that is ignored in our society nowadays is an important issue that can be taught in history learning based on local history that is really important to be delivered to the students so that they can understand historical incident around them.

Various social phenomena that emerged lately quite worrying. The phenomenon of violence in solving the problem becomes common. The emphasis and coercion of the will of one group to another is considered normal. It seems that the character of Indonesian society is polite in behaving, deliberation of consensus in resolving the 
problem, local wisdom rich with plurality, solidarity, and mutual cooperation has transformed into hegemony of new groups that beat each other [2].

Indonesia diversity can trigger student's conflict one of them can happen on Vocational School. Many quarrels happen among students in many schools. It is commonly happen because of simple problems such as contrast opinion or goal even personal problem. The conflict shows the lack of solidarity among students especially vocational students.

The lack of a sense of social solidarity in the limited scope of the school environment is an illustration of how the students' social solidarity will be if they live in a wider society. The life of such a diverse society demands a person living in it with social solidarity. for that social solidarity needs to be improved among students of SMK, the goal is to minimize various forms of disputes between students and prepare students to live in a diverse society. Learning local history has a strategic role in promoting social solidarity among students.

Local history can be one of history learning material can be delivered to the students so that they know about history incident in their daily life. Many positive things in history incident can be a good example to student's life, grows sense of solidarity, keep and protect historical heritage, and know about multi cultural around them.

In addition, according to Nana Supriatna [3] historical learning can be done in a dialogical and democratic manner that allows students to develop values relevant to the condition of a pluralistic and global society but not contrary to the reality of everyday life [2]. As stated in Law Number 20 Year 2001 on the National Education System states that national education functions to develop the ability and form the character and civilization of a dignified nation in order to educate the nation [4].

According to Arifin [5], studying local history becomes one of the efforts to find alternative solutions to address the impact of globalization that is increasingly penetrated into all aspects of community life. Facing globalization with all its impacts will require various approaches to deal with it. Thus all the potential possessed by a nation must be optimized. The local cultural system is a great social capital (social capita), has grown hereditary to the present strongly entrenched in the community [3].

Local history learning material in Pekalongan that can be used for improving student's solidarity is Kebon Rojo Incident on October 3rd 1945. The material can describe about struggle of Pekalongan people in defending of Indonesian's independence by taking over Japanese weapon and power. The struggle values can be implemented in daily life through education until education is seen as an effort to strengthen sense of nationalism, religiousness, and solidarity as well.

\section{RESEARCH METHOD}

The method used in this research is descriptive qualitative method so as to produce descriptive data about learning history in SMK. Data collection techniques use in-depth interviews, observation, and document analysis, which aims to extract specific 
information through a series of questions submitted by the researcher to the respondent. So as to produce descriptive data on learning at the level of Vocational High School. The researcher focuses the analysis on the teacher of Indonesian History subjects derived from SMK Negeri 1 Kedungwuni. The analytical technique used is data reduction that aims to direct, classify, then sharpen, remove unnecessary, and organize data so that final conclusions can be obtained [6].

\section{Local History Learning}

Learning is the process of interaction of learners with educators and learning resources in a learning environment. Interaction is meant in this learning process is social interaction, namely the relationship between individuals and groups, in this case the teacher as an individual interacts with a group of learners [7].

According to Heri Susanto [8], in learning history learners are expected to gain knowledge about the facts. Students is also expected be able to develop knowledge about causality connection among the facts. History has important role in understanding human being in social scope and its own social structure. History learning is reputed important to show a strong sense about intellectual attitude and national integrity. History learning can give an inspiration to the students that social process in complexities of problem in society that needs an understanding.

Based of Permendiknas No. 22 Tahun 2006 about the standard of content that history materials [9] are:

1. Containing heroic example, pioneering, patriotism, and nationalism values, and spirit to never give up that base character building process personality of students.

2. Containing treasure about nation's civilization, include Indonesia civilization. The material is a basic learning material to the process of Indonesia civilization building in the future.

3. Growing sense of unity and brotherhood and solidarity as well to become a nation adhesive in facing national disintegration.

4. Full of moral and wisdom teaching to overwhelm multi dimensional crisis in daily life.

5. Growing and developing sense of responsibility in keeping nature balance.

From the results of observations and interviews at SMK Negeri 1 Kedungwuni, Pekalongan, that history teachers only convey the material to rely and in accordance with what is in the compulsory book[10]. The teacher does not try to develop basic competent based on local history on Pekalongan nor student's character. The teacher also never discusses something interesting and relating to student's life. Although in every area in Indonesia has diversity in many thing, one of them is local history as one of national assets.

According to Bandura (in Muhibbin Shah [11]), an individual has a proactive ability to develop in his environment, they always practice in developing and controlling themselves and interacting in order to achieve their goals. From these 
statements we can understand that the values of a historical event can be implemented in the life of students if during the learning process there has been motivation and habituation.

Therefore, through local history learning process, student can learn patriotic values in every history incident that can be applied in daily life. So that small good habit but meaningful can fulfill their soul. Thus, learning local history is expected can grow solidarity and self identity, increasing passion and building the good character to the students.

Local history learning in districts especially in Pekalongan is one of culture heritage that is rich of treasure values for generations. Based on the text above, history learning has function to make students realize that change and development process in our society does exist. In this case, local history that is October $3^{\text {rd }} 1945$ incident has important role to develop the material and social solidarity through patriotic values within the incident.

\section{October $3^{\text {rd }} 1945$ Incident on Pekalongan}

According to Abrar Yusra and Ramadan [12], Pekalongan has been noted as one of batik industrial city in Indonesia. It is located on the north coast of Java and categorized as an old city with some historical buildings that still can be found now. Because of the strategic location, Pekalongan people being more open minded with the society and foreign culture such as China, Arab, and India.

Anton E. Lucas [13], Since Japan colonization on Indonesia, Japan propaganda troop do not stop to do their action. On March $17^{\text {th }} 1942$ Japan arrived on Pekalongan. At first, the people welcomed Japan arrival because Japan said that they are Indonesian older brother. However, they did violence to the people. Colonization and exploitation made Indonesian people hated them.

According to Horton and Hunt [14], power refers to an ability to control the activities of others despite the will of the parties concerned. The power possessed by the colonialists was used to compel the adherence of the local people, thereby forcing the local community to follow it. In an effort to oppose the Japanese government, Pekalongan people prioritize cooperation, solidarity, and put aside differences to achieve its goals.

Pekalongan people who hated Japanese governance tried to against them by using organizations established by Japan. One of them is Putera (Pusat Tenaga Rakyat/ People Power Center) to unite people power [15]. Many other organizations are also used to against them whether young, old, woman, and man to fight for the freedom [16].

Interview with Mr. Tasbun, A few days after the proclamation was announced the establishment of the Indonesian National Committee (KNI/Komite Nasional Indonesia) of Pekalongan Region as the executive body responsible for the taking of power to assist the duties of the regional head, to conduct preliminary negotiations with the Japanese to take over both civilian and military [17]. KNI also helped to unite all movement to 
against Japan. KNI branch Pekalongan always worked together with Badan Penolong Keluarga Korban Perang (BPKKP/ Bureau of Rescuer for War Victim Family) and youngsters on Pekalongan [18].

There are three organizations on Pekalongan that tried to arrange the taking over process from Japan. They are KNI Pekalongan, BPKKP Pekalongan, and young fighters on Pekalongan. They always had meeting to arrange the attack or discussion about taking over process on BPKKP office. The result was they would try to discuss with the Japanese [19]. It was because Japanese did not go out from Pekalongan even Indonesia independent day was proclaimed.

The negotiation was decided on October $3^{\text {rd }} 1945$ at 10 a.m on Kempeitai office. Many members of Indonesia or Pekalongan contingent consists of Mr. Besar and members of KNIP Pekalongan. The leader of delegation was dr. Soembadji. Then, it was decided three verses from Indonesia to Japan delegation.

According to one witness, Mr. Fadholi, the people finally flocked to Kebon Rojo Square to witness their representatives negotiating with the kempeitai on October $3^{\text {rd }}$, 1945 that started at 10 a.m. At that time, the air was getting warmer and they felt the spirit in the air. While Horizumi translating Dr. Ma'as speech to Tokonami, suddenly there was shoot sound from outside. Next couple seconds it was silent, then the crowd was really noisy. The flag waving by Rahayu, Bismo, and Mumpuni was a symbol of nationalism from the idealist youth without afraid of the risk [20].

In Anton E.Lucas [13], PETA Pekalongan's Daidancho Battalion, Iskandar Idris, tried to call Daidancho Sudirman (Sudirman the Great Commander) on Pekalongan. Then, Iskandar Idris told about situation on Pekalongan and asked for his help in order to call Butaicho that supervised Japanese soldier all over banyumas and Pekalongan residen in order to attract them out from Pekalongan. Then, Sudirman was enabled to do so and would call Pekalongan representative next. Japanese employee went from Pekalongan at 04.30 a.m. to Purwokerto through Tegal by BKR truck so that on October $7^{\text {th }} 1945$ Pekalongan was free from Japanese domination [21].

In an effort to combat the atrocities of the Japanese government, Pekalongan people prioritize cooperation, solidarity, and put aside differences to maintain independence. The values of solidarity that exist in the Kebon Rojo Incident on 3 October 1945 in Pekalongan will later be applied in the learning of history.

Based on Durkheim's opinion, without "similarity unsure" there will not be cooperation, social solidarity, or social life. The main job of society is to building a person becomes unity on social solidarity. History learning and education connects between a person and society. Durkheim said that a kid has to learn how to cooperate to others who are not his sibling or classmate. School in this case will provide many skills they can learn. School is a miniature of society or a model of social system where a student has to have interaction with people in school according to their own role [22]. 
On the other hand, Parson said that school is to preparing person bases transition step from family to society who each person has different role. Furthermore, Parson explained that school has job to educate about universal values. These values have to be learnt so that a person can be accepted in a society [23].

\section{The Solidarity of Vocational School Student}

Based on the results of data analysis that has been collected previously through observation or interview there are three things to note, namely the understanding of teachers and students about local history, values of sodaritas in Kebon Rojo's Incident History October 3, 1945 in Pekalongan, and the application of values of solidarity in learning. From the data that has been collected, initially the history teacher at SMK Negeri 1 Kedungwuni not yet understand the importance of local history to increase the value of solidarity in students. Then, the history teacher tried to make a teaching material about Kebon Rojo Incident on October 3, 1945. It turned out that after implemented in teaching and learning activities about the value of student's solidarity behavior become more positive, such as the spirit of higher learning, increasing the quality of teacher relationship with students which is marked by the increase students' respect for teachers, and a more conducive class atmosphere. Although this assessment is only qualitative in nature, at least teachers have a belief that local history in Pekalongan can increase the value of solidarity for the development of their.

Durkheim said that solidarity shows a condition about the connection between a person and or a group based on the sense on moral and belief that they trust and be strengthened by collective emotional experience. Solidarity stressed on the condition of connection among people in a group and bases a cooperative link in a life with moral and belief values in a society. Besides having a high solidarity, Indonesia people also have other noble values such as mutual cooperation, discussion, harmony, and etc [23].

Solidarity is an important thing that must be watched and be improved in student soul on vocational school since there are many conflicts among students. History subject has a strategic role in increasing student's solidarity through applying patriotic values in Pekalongan society on October $3^{\text {rd }} 1945$ incident. In this case, solidarity is not for attacking Japanese as colonial but for facing globalization with it effects such as diversity and minimizing conflicts that commonly happen nowadays.

Applying local history learning on vocational school is by habituation during learning process so the student needs to know about the solidarity before studying the subject. As Koentjaraningrat said that social solidarity is a solidarity that shows on the condition of a connection between a person or a group based on a moral and belief that is followed by many people and strengthened by collective emotional experience [24].

After knowing solidarity, student is lead to find solidarity values on Kebon Rojo Incident. Student is lead to apply during learning process by discussing group. The teacher can see how a student studies in a group, presents the result, asks questions, answers or gives respond, and finishes several questions related to solidarity. 
In the class, student can learn Pekalongan local history that is October $3^{\text {rd }} 1945$ incident through discussion group. This discussion group is a method that gives hope history teacher to reach academic and social-moral goals. Discussion group can increase sense, take and give, and trust each other among students and increasing a pro social attitude.

Through student centered learning, there will be a great human resource that succeed gaining learning experience on certain competence. Student not only gets knowledge or skill, but also involves in whole process. In consequence, student is well-trained to apply the knowledge or skill according to the society [25].

\section{CONCLUSION}

Learning local history becomes one of effort to look for alternative solution in facing globalization on every part of our life. Diversity in Indonesia can cause a conflict such as in vocational school environment. Therefore, through learning process on local history, the student can learn patriotic values in every history incident that can be applied in daily life.

The function of school is to prepare a person from a family to a society that each has different role. The material of local history learning in Pekalongan that is used for increasing student's solidarity is Kebon Rojo Incident. In order to against Japan governance, Pekalongan people worked together, had solidarity, and throw away the difference to keep the freedom.

In this case, solidarity is not about against Japanese but about globalization and upcoming problems such as society diversity and for minimizing conflicts that is caused by diversity of religious and ethnic.

\section{REFERENCE}

[1] Rahyono, Kearifan Budaya dalam Kata. Jakarta: Wedatama Widyasastra, 2009, p. 25

[2] Taufik Abdullah, Sejarah Lokal di Indonesia. Yogyakarta: Gajah Mada University Press, 2005, p. 12.

[3] Nana Supriatna, Pembelajaran Sejarah dalam KTSP. Disampaikan dalam Semiloka Guru-guru Sejarah MGMP Sejarah Kota Bandung, 2007, hlm. 14.

[4] Depdiknas, 2003, Undang-Undang Republik Indonesia No.20 Tahun 2003 tentang Sistem Pendidikan Nasional. Surabaya: Karina.

[5] Arifin, dkk, Kajian Sejarah Mikro sebagai Muatan Lokal. Surakarta: Sebelas Maret University Press, 2012, p. 30.

[6] Miles, M.B, Huberman, A.M, and Saldana, J, Qualitative Data Analysis: A Methods Sourcebook, London: Sage Publications Inc, 2014, p. 35.

[7] Yatim Riyanto, Paradigma Baru Pembelajaran. Jakarta: Prenada Media Group, 2012, p. 41. 
[8] Heri Susanto, Seputar Pembelajaran Sejarah, Isu, Gagasan, dan Strategi Pembelajaran. Yogyakarta: IKAPI, 2014, p. 49.

[9] Aman, Model Evaluasi Pembelajaran Sejarah. Yogyakarta: Universitas Negeri Yogyakarta, 2011, p. 57.

[10] Interview result with History teacher on SMK Negeri 1 Kedungwuni, SMK Islamiyah Sapugarut, SMK Muhammadiyah Bligo, SMK Gondang Wonopringgo.

[11] Muhibbin Syah, 1995. Psiologi Pendidikan: Suatu pendekatan baru. Bandung: PT. Remaja Rosdakarya, Hlm. 79.

[12] Abrar Yusra dan Ramadhan KH, Hoegeng: Polisi Idaman dan Kenyataan (Sebuah Autobiografi). Jakarta: Pustaka Sinar Harapan, 1993, p. 24.

[13] Anton E. Lucas, "One Soul One Struggle", a.b. Anton E. Lucas.Peristiwa Tiga Daerah: Revolusi dalam Revolusi. Jakarta: Pustaka Utama Grafiti, 1989, p.37.

[14]Horton, Paul B. \& Hunt, Chester L, Sosiologi Jilid 1 (edisi keenam). Jakarta: Erlangga, 1984, hlm. 379.

[15] Marwati Djoened Poesponegoro dan Nugroho Notosusanto, Sejarah Nasional Indonesia VI Zaman Jepang dan Zaman Republik Indonesia (1942-1998). op.cit.,Jakarta: Balai Pustaka, 2010, p. 43.

[16] Proyek Penelitian dan Pencatatan Kebudayaan Daerah, Sejarah Kebangkitan Nasional Daerah Jawa Tengah, Jakarta: Departemen Pendidikan dan Kebudayaan, 1978, p. 161.

[17] Anthony J. S. Reid, "The Indonesian National Revolution", a.b. Pericles G. Katoppo. Revolusi Nasional Indonesia. Jakarta: Pustaka Sinar Harapan, 1996, p. 51.

[18] Interview with Mr. Tasbun was conducted on January 10, 2013 at his house Jalan Kusuma Bangsa, Kandang Panjang Pekalongan.

[19] Lucas, Anton, "Pemuda Revolusi", Dalam Wild, Collin dan Peter Carey (Ed), Gelora Api Revolusi Sebuah Antologi Sejarah. Jakarta: Gramedia, 1986, p. 157.

[20] Interview result with Fadholi on January 7th 2013 in his house on Jalan Hayam Wuruk Sampangan Gg.10, Pekalongan.

[21] Dewan Harian Cabang Angkatan 45, Pertempuran 3 Oktober 1945. Pekalongan: Kotamadya Dati II Pekalongan, 1992, p. 12.

[22] Sartono Kartodirdjo, Pendekatan Ilmu Sosial dalam Metodologi Sejarah. Jakarta: Gramedia Pustaka Utama, 1992, p. 62.

[23]G. Ritzer, Teori Sosiologi dari sosiologi klasik sampai perkembangan terahir Postmodern. Yogyakarta: Pustaka Pelajar, 2012, p. 147.

[24] I Gde Widja, Sejarah Lokal dalam Pengajaran Sejarah, Jakarta: Departemen Pendidikan dan Kebudayaan, 1989. p.129.

[25] Koccar S.K, Pembelajaran Sejarah. Translator Purwanta and Yofita Hardiwati, Jakarta: Grasindo, 2008, p. 5. 